\title{
Impact of Socio-Psychological Work Environment on Teachers' Job Commitment in Public Primary Schools in Mwatate Sub- County, Kenya
}

\author{
Genevieve Wanjala $^{1^{*}}$, PhD, Mwashigadhi Lonex Joram², Med. \\ ${ }^{I}$ Department of Educational Adminstration \& Planning University of Nairobi Kenya (Assoc. Professor: \\ Educational Planning), Kenya \\ ${ }^{2}$ Teacher of Kiswahili and History Vichwala Primary School P.O. Box 1063-80304 Wundanyi, Kenya
}

*Corresponding Author: Genevieve Wanjala, PhD, Department of Educational Adminstration \& Planning University of Nairobi Kenya (Assoc. Professor: Educational Planning), Kenya

\begin{abstract}
This research explored the effects of social and psychological working environment on teachers' job commitment in public primary schools in Mwatate Sub-County, Kenya. The objectives of the study were to determine the extent to which the socio-psychological work environments as well as job security influence teachers' job commitment. We used descriptive survey research design and focused on 63 head-teachers and 315 teachers from the 63 public primary schools in the region as the target population. The sample size was 94 respondents, made up of 17 head-teachers and 95 teachers who were randomly sampled based on the 30\% rule. Questionnaires were used to collect data which was analysed using appropriate descriptive statistics. The research has established that there was a significant relationship between the working conditions and the level of job commitment. The study recommends that the Ministry of Education should strive to improve sociopsychological work environment in public primary schools and formulate strategies that can improve the affective, normative and continuance commitment scales of teachers through teacher-pupils contact time.
\end{abstract}

Keywords: Work Environment, Teacher Commitment, Public Primary Schools

\section{INTRODUCTION}

Throughout the ages Education has empowered humanity towards greater heights of development since it has played an emancipator role for citizen towards enlightenment. This implies that education is and will continue to be recognized as fundamental right and a basic need for every child anywhere in the world. According to Diwani (2007) Education is considered a basic tool for fighting poverty and ignorance, particularly in the developing countries. Thus, teachers are essential players in promoting delivery of quality education because the success of the objectives of learning is significantly influenced by the state of and the mindsets of teachers. Committed teachers portray elements that illustrate enthusiasm, dedication, low turnover, staying at work for extra time as well as attracting other people to the teaching job. Indeed Mutwiri (2015) suggests that apart from improving institutional factors like provision of teaching and learning materials, supervision and enhancing reward strategies, stakeholders in education should also devise ways of enhancing job satisfaction and commitment of the teaching force. .Yet in Mwatate Sub County, some teachers show low levels of enthusiasm and others opt to quit teaching in public primary schools.

As Steers (1977) has explained, individuals join organizations because of their needs and desires, so they expect an environment where they can nourish their dreams and have their needs get satisfied. Hence, teachers like any other professionals seek employers who offer permanent and pensionable tenures which are perceived as secure. Job security is one of the expectations of teachers, since secure jobs motivate them. In fact Mercurio (2015) confirmed that "affective commitment was found to be an enduring, demonstratable indispensable and central characteristic of organizational commitment" .This implies that affective commitment is the core component that focuses attitudes by employees towards the organization they are working for .It embraces the other components of commitment because ,it deals with the psychological perceptions of an employee. 
In Mwatate Sub County, both the Teachers' Service Commission (TSC) and the schools' Boards of Management (BoMs) employ teachers. All these teachers continue to work under same job descriptions as stipulated but they are remunerated differently. The issue of job security is worse for the BoM teachers who serve under temporary terms of employment with low salaries, no medical benefits, no housing allowances, no membership of social welfare associations and no pension accruals. In terms of working conditions, some schools in Mwatate Sub County have failed to provide physical facilities and infrastructure as well as learning materials for handling the large classes. Some schools have semi-permanent classrooms and buildings with poor roofing. Some teachers in parts of Mwatate work under very strenuous conditions like shortages of water, insufficient means of transport and threats from wild animals from the neighboring Tsavo West national park. Yet, hardship allowance is paid by TSC to only a few teachers who are under its employ. What effect does this inequitable working environment have on the teachers' job commitment?

\subsection{The Concept of Commitment}

Commitment refers to an employee's willingness to work positively in an organization and his or her continuance to work for it (Mowday, et al, 1982). In this respect, commitment implies an employee's continuous effort to render personal efforts to the organization regardless of the working conditions being experienced by the said employee. Buchanan (1974) sees commitment as a sort of bond between an employee and the organization that the employee is working for and adds that it is by a variety of factors that are related to the employee's personal behavior as well as the external environmental factors.

Job commitment entails a close relationship between the employees and the organization they work for. This close relationship ought to commence at the time when an employee is being recruited into an organization and goes on with time up to and including the employee's retirement time. Commitment is an important pillar towards the successful human resource management of an organization. It greatly contributes towards the overall achievement of the aims and objectives of any organization and is, thus, an inevitable issue that should concern the management, directors and the policy makers of an organization.

It is for this reason that Shore and Martin, (1989), Siders et al,(2001) and Meyer et al, (2002) continue to insist that organizational commitment directly affects employee's performance and therefore management should strategize on how to achieve and win total and maximum commitment from their employees in their respective organizations. Committed employees contribute to the overall achievement of goals and aims as well as to the life and wellbeing of any organization. Moreover organizational commitment is significantly related to satisfaction which inevitably enhances professional performance of duties assigned. As has been stated earlier, Mercurio (2015) confirmed that "affective commitment was found to be an enduring, demonstratable indispensable and central characteristics of organizational commitment" Moreover, affective commitment is the core component that focuses attitudes by employees towards the institution that they are working for .It embraces the other components of commitment because, it deals with the psychological perceptions of an employee.

\subsubsection{Socio-psychological Work Environment and Teachers Job Commitment}

Armstrong (2009) explains that work environment consists of the systems of work, the design of jobs, working conditions and the ways in which people are treated at work by their managers and by coworkers. A conducive socio-psychological work environment can be achieved when account of job needs is taken while designing the work system. This implies that managers and supervisors need to ensure that their organizations offer favorable working conditions for the employees in order to maximize their productivity. Care and precaution need to be taken in the provision of this conducive socio-psychological work environment.

Armstrong's findings concur with earlier researches which focused on the welfare of the workers. For instance, Warr et al, (1970) illustrates that a good socio-psychological work environment should take into consideration workers involvement, job motivation, job satisfaction and happiness. Workers ought to be treated as full human beings with personal needs, hopes and anxieties. When employees are offered a good working atmosphere, they develop innovativeness, self-control and confidence and if well rewarded for the work done, they develop higher levels of job commitment. 
Gupta (2009) describes a work environment as comprised of the physical, mental and social aspects. Physical environment has to be provided by the management of the institution on matters like wellventilated classrooms, adequate lighting in buildings among others. Mental environment comprises the psychological influence on attitudes and behavior of workers as a result of expectations from their managers and leaders. Good leaders inspire the workers to put in their best. Social environment involves the constructive use of groups. Heads and leaders of the groups influence the attitudes and behavior of individual workers towards the organization. Taking a cue from the foregoing discussion, this research was conducted with the aim of determining the relationship between socio-psychological work environment and teachers' job commitment.

\subsubsection{Job Security and Teachers' Job Commitment}

One of the aspirations of any employee is job security. Job security eliminates any sort of job uncertainty and leads to the prevention of unpredictable outcomes. Job security affects employee's job commitments. In their study, De Cuyper, et al (2009) found that, workers who are on fixed term contracts or considered 'temporary workers, reported higher levels of job insecurity than the permanent workers. In other words, job security is positively correlated to job satisfaction and commitment in permanent workers. From their findings, it can be concluded that employees feel secure if they are hired on permanent and pensionable terms. Permanent workers in an organization feel a sense of belonging to the organization and can develop affective commitment to it than temporary workers.

Meyer and Allen (2002) further state that an employee who is affectively committed, strongly identifies with the goals of the organizations and desires to remain part of the organization for a long period of time. They went on to clarify the correlation between commitment and job security in what they stated as "a positive relationship between tenure and commitment which may be due to tenurerelated differences in job status and quality". An organization with varied terms of employment such as permanent, temporary or fixed contract will experience varied levels of affective commitment from its workers.

Malhotra et al(2007) show that employees non-monetary aspects like house leasing, free medical facilities, insurance cover, unprotected loan facilities, pension bonuses, annual increments and provision of leaves facilities, are more powerful predictors of affective commitment than salary package since they secure tie employees' job interest to the organization. Otherwise, in case of unfair treatment of workers by the management on matters pertaining to their nature of employments, there would be varied levels of affective commitments by employees as Levine (1993) warms that where inequity exists, employees may attempt to reduce the distress by changing their perceptions. It is important to note that the provision of best quality products and services to a teacher by employer is closely associated with permanent employment basis which has higher levels of job security. In this research therefore, we considered job security as a predictor of teacher commitment and attempted to establish how job security influences teachers' job commitment.

\subsection{Statement of the Problem}

In Kenya, like in other countries in Africa, teachers continue to occupy vital position in the society because of the role that they play towards imparting relevant knowledge, useful skills and desirable attitudes to the learners in order to make them fit well in their future lives, apart from just excelling in their examinations. Nevertheless, the situation of teacher commitment in public primary schools in Mwatate Sub County is in a declining situation. The Taita Taveta Task force Report (2013) on Educational declining trends in Taita Taveta, pointed out some issues that relate to teacher commitment. Teaching is a demanding career that involves long hours of standing, vigorous practical lessons and adequate prior preparations. However, the teachers in the sub-county lack devotion, dedication, energy and enthusiasm in that they cannot engage themselves to undertake extra tasks beyond working hours. In Rong'e zone teachers are denied hardship allowance by TSC which the rest of the teachers in Mwatate Sub County receive. Some teachers quit teaching in public schools and opt for 'greener pastures' in private schools. Making one ask questions, such as does job security have significant relationship with teachers' job commitment in the region studied?? Does the schools' socio-psychological work environment influence commitment to the teaching job? These are the questions that this research was trying to answer. 


\subsection{Theoretical Framework}

The study was based on the theory of the Three Components Model (TCM) of commitment (Meyer \& Allen; 1991; 1997; 2002) which is ideal in studying workplace commitment. The study attempted to assess the application of the variety of mindsets pertaining to employee commitment to an organization. The independent variables in this study; socio-psychological work environment can be categorized as either desire-based (affective commitment), obligation -based (normative commitment) or cost-based (continuance commitment). The theory also stipulates that the validated scales; that is, (a) affective commitment scale, (b) normative commitment scale and (c) continuance commitment scale may be used as a guide in measuring the three components of commitment of employee in an organization.

Meyer and Allen (2002) pegged affective commitment (AC) as the 'desire' component of commitment. Employees with strong affective commitment opt to stay because they want to. Those with strong normative commitment stay because they feel they ought to do so as an obligation, while those with strong continuance commitment choose to stay because they have to do so not to lose their socio-economic gains. The other component is target commitment, meaning affiliation to an organization and the behavior commitment that predicts employee either to remain or stay or quit.

Put in another way, affective commitment is defined as the employees' emotional attachment to the organization Meyer and Allen described it as desires to continue identifying strongly with the goals of the organization. An employee who is committed desires to remain part of the organization due to work related factors like; Job status, age, tenure or education. Continuance commitment deals with commitment to continue working in an organization because of inter-employee relation and other nontransferable investments like pension, retirement benefits and social friendship ties with co- worker. Normative commitment is whereby an individual commits to and remains with an organization because of the feelings of obligation .These feelings may come from a strain on an individual before and after joining the organization .For instance an employee feels a moral obligation to serve in a company that has invested resources in his or her job training.

Meyer and Allen's TCM model received criticism from other psychologists who claimed that it was not consistent with the empirical findings and that it combines different attitude phenomena. Although the TCM was a good way to predict turnover, these psychologists did not believe it should be the general model. They claimed that TCM mixes together attitudes towards behavior (organization) and target towards behavior (staying or quitting). Scholars of management psychology, in that regard, developed a five component commitment model that puts into consideration the issue of consumption of product and service. A good example is Solinger et al ,2008) who responded by designing a model that proposes two additional components of habitual commitment and forced commitment apart from the initial TCM .They claimed that people get habituated to the job by its nature. In other words, routine processes can make people develop a sort of commitment towards their job. They believed that any model should be able to explain organizational commitment as an attitude towards the organization and measure it accordingly.

However, it became clear that affective commitment equals an attitude towards a target (i.e. an organization) whereas continuance and normative commitment can be used to represent different concepts in anticipated behaviour outcomes (meaning to staying or quitting). This laid down the foundation for accepting affective commitment to have stronger associations with a relevant behavior and wider range of behavior compared to normative and continuance commitment. Buitendach $\&$ De Witte (2005) have further pointed out that the affective dimension of commitment has been found to be most strongly related to positive occupational and organizational outcomes such as; job satisfaction, motivation and employee retention. Affective commitment in this context refers to the employee's positive emotional attachment to the organization that the said employee is working for. Thus, the strongest component of commitment on performance is on affective commitment (the desire component) followed by normative commitment and continuance commitment.

\section{RESEARCH METHODOLOGY}

\subsection{Research Design}

This study adopted the descriptive survey design which we the researchers considered as suitable because it provided a wide scope towards describing, recording, analyzing and interpreting data about 
two key socio-psychological factors influencing teachers' job commitment namely the work environment and job security This design was useful in describing the characteristics of respondents of a large population using the samples made, thus making the data interpretation statistically significant.

\subsection{Target Population}

The total environment of interest to this research, which was carried out between January and December of 2017. Comprised of all the public primary schools in Mwatate Sub-County, Kenya According to the County Education Office there were 63 public primary schools 63 head-teachers of the said schools and 315 primary school teachers in the sub-county at the time of the research study.

\subsection{Sample Size and Sampling Procedures}

The purpose of this study was to investigate institutional factors influencing teachers' job commitment in public primary schools in Mwatate sub county, Kenya. To this effect, the researchers stratified the respondents into head-teachers and teachers. Using the simple random sampling technique, the researcher selected $30 \%$ of the 63 schools which yielded a total of approximately 19 schools to be used for the study. Of these, 2 schools were used for piloting of the research instruments; thus, giving 17 public primary schools to participate in the actual study. This is in line with Kombo and Tromp (2006) who suggested that a 30\% of the target population would make an appropriate sample for a research study in the social sciences. Similarly, thirty percent of the teachers were sampled from the total number to get 95 teachers. The total sample size for research was as shown in Table 1.

Table1. Sample size of the respondents

\begin{tabular}{|l|l|l|}
\hline Respondents & Target & Sample Size \\
\hline Head Teachers & 63 & 17 \\
\hline Teachers & 315 & 95 \\
\hline Totals & $\mathbf{3 7 8}$ & $\mathbf{1 1 2}$ \\
\hline
\end{tabular}

\subsection{Research Instruments}

The tools that were considered most appropriate for data collection in this research study were (1) the questionnaire. and (2) direct observation. The researchers constructed two sets of questionnaires; one was designed for head teachers and the other for teachers. In triangulation, direct observation was also used as a tool for data collection

\subsection{Research Objectives and Research Questions}

The objectives of the study were;

- To determine the influence of socio-psychological work environment on teachers' job commitment in public primary schools in Mwatate sub-County.

- To determine the influence of job security on teachers' job commitment in public primary schools in Mwatate sub-County.

In order to achieve these objectives, the study was guided by the following research questions;

- To what extent does socio-psychological work environment influences teachers' job commitment in public primary schools in Mwatate sub county?

- To what extent does job security influences teachers' job commitment in public primary schools in Mwatate Sub County?

\section{RESEARCH FINDINGS AND DISCUSSION}

Out of 17 questionnaires administered to the school head-teachers, 17 of them were completed and returned making a questionnaire return rate for the head-teachers to be 100 percent. For the teachers 95 out of 95 questionnaires were completed and returned making a total questionnaire return rate to be 100 percent. The return rate of 100 percent was considered representative enough. and adequate for analyzing and reporting results. 


\subsection{Research Question 1: To what extent does socio-psychological work environment influence teachers' job commitment in public primary schools in Mwatate Sub-County?}

The first objective of the study sought to determine whether socio-psychological work environment influence teachers' job commitment in public primary schools in Mwatate Sub-County Kenya. In measuring the influence of socio-psychological work environment on teacher's job commitment, the respondents were issued with statements to which they were expected to respond using the likert scale: Strongly Agree (SA), Agree (A), Not Sure (NS), Disagree (D), and Strongly Disagree (SD). Headteachers' responses are captured in Table 2

Table2. Headteachers' perception on influence of socio-psychological work environment on teachers' job commitment

\begin{tabular}{|l|l|l|l|l|l|l|l|l|l|l|l|}
\hline \multicolumn{1}{|c|}{ Item } & \multicolumn{2}{c|}{ SA } & \multicolumn{2}{c|}{ A } & \multicolumn{2}{c|}{ NS } & \multicolumn{3}{c|}{ D } & \multicolumn{1}{c|}{ SD } \\
\cline { 2 - 10 } & $\mathbf{F}$ & $\mathbf{\%}$ & $\mathbf{F}$ & $\mathbf{\%}$ & $\mathbf{F}$ & $\mathbf{\%}$ & $\mathbf{F}$ & $\mathbf{\%}$ & $\mathbf{F}$ & $\mathbf{\%}$ \\
\hline $\begin{array}{l}\text { I frequently socialize with my junior } \\
\text { officers outside workplace. }\end{array}$ & 8 & 47.1 & 7 & 41.2 & 2 & 11.8 & 0 & 0.0 & 0 & 0.0 \\
\hline $\begin{array}{l}\text { My seniors' officers invite me to } \\
\text { socialize outside workplace. }\end{array}$ & 4 & 23.5 & 2 & 11.8 & 0 & 0.0 & 9 & 52. & 2 & $\begin{array}{l}11 . \\
8\end{array}$ \\
\hline $\begin{array}{l}\text { I feel there is fair treatment among } \\
\text { teachers in the school. }\end{array}$ & 9 & 52.9 & 7 & 41.2 & 0 & 0.0 & 1 & 5.9 & 0 & 0.0 \\
\hline $\begin{array}{l}\text { This is the best employer teachers } \\
\text { should work for. }\end{array}$ & 11 & 64.7 & 6 & 35.3 & 0 & 0.0 & 0 & 0.0 & 0 & 0.0 \\
\hline $\begin{array}{l}\text { I offer the best socio-psychological } \\
\text { work environment for teachers to work }\end{array}$ & 15 & 88.2 & 2 & 11.8 & 0 & 0.0 & 0 & 0.0 & 0 & 0.0 \\
\hline
\end{tabular}

Information presented in Table 2 shows that most of the headteachers were for the opinion that sociopsychological work environment influenced teachers' job commitment. For instance, $17(100 \%)$ of the head-teachers felt that there is fair treatment among teachers both in and out of the school in fact 88.2 percent of them strongly indicated that they offer the best socio-psychological work environment for teachers to work in. This showed that they were willing to create a free working relationship that is conducive for job commitment. However, a close observation revealed that almost $90 \%$ of the teachers did not reside within the school premises making it very expensive for them to engage in any meaningful social activities together. This is in line with Farrell (1993) who observed that teachers who fail to get institutional houses have to look for accommodation elsewhere, a situation which results into demoralized teachers and hence unable to effectively perform at work.

Using the same tool, the teachers were also asked to rate on their responses regarding influence of socio-psychological work environment on their job commitment and their responses are recorded in Table 3.

Table3. Teachers perception on influence of socio-psychological work environment on teachers' job commitment

\begin{tabular}{|c|c|c|c|c|c|c|c|c|c|c|}
\hline \multirow[t]{2}{*}{ Item } & \multicolumn{2}{|c|}{ SA } & \multicolumn{2}{|c|}{$\mathbf{A}$} & \multicolumn{2}{|c|}{ NS } & \multicolumn{2}{|c|}{ D } & \multicolumn{2}{|c|}{ SD } \\
\hline & $\mathbf{F}$ & $\%$ & $\mathbf{F}$ & $\%$ & $\mathbf{F}$ & $\%$ & $\mathbf{F}$ & $\%$ & $\mathbf{f}$ & $\%$ \\
\hline $\begin{array}{l}\text { I frequently socialize with my co- } \\
\text { teachers outside the workplace. }\end{array}$ & 9 & 9.2 & 12 & 12.6 & 4 & 4.2 & 6 & 6.3 & 64 & 67.4 \\
\hline $\begin{array}{l}\text { My senior officers regularly invite me } \\
\text { to socialize outside the workplace. }\end{array}$ & 0 & 0.0 & 0 & 0.0 & 0 & 0.0 & 33 & 34.7 & 62 & 65.3 \\
\hline $\begin{array}{l}\text { I feel that I have equal status with my } \\
\text { peers in the school. }\end{array}$ & 71 & 74.7 & 19 & 20.0 & 5 & 5.3 & 0 & 0.0 & 0 & 0.0 \\
\hline $\begin{array}{l}\text { I find that my values and my } \\
\text { employer's values are very similar. }\end{array}$ & 64 & 67.4 & 12 & 12.6 & 4 & 4.2 & 9 & 9.5 & 6 & 6.3 \\
\hline $\begin{array}{l}\text { For me, this is the best of all possible } \\
\text { organizations for which to work. }\end{array}$ & 77 & 81.1 & 11 & 11.6 & 0 & 0.0 & 3 & 3.2 & 4 & 4.3 \\
\hline
\end{tabular}

From the findings in Table 3 it emerged that socio-psychological work environment in most schools (74.7\%), influenced teachers' job commitment. Most teachers felt that they have equal status with their peers in the school. These findings showed that majority of the schools in Mwatate Sub-County offered a conducive environment for teachers which enhanced their $r$ job commitment. This finding concurs with a study done in India that noted that teachers who are not given conducive sociopsychological work environment in the school have great difficulty in performing even the most 
routine tasks. The working condition contributes to teacher morale in executing their duties in school and hence affects the level of their job commitment, (Ramachadran, Jain, Shekar, Sharma \& Pal, 2005).

Further, the researchers were interested in knowing the extent to which socio-psychological work environment enhance individual teacher's job commitment. The responses are recorded as displayed in Table 4

Table4. Extent to which socio-psychological work environment influence teachers' job commitment

\begin{tabular}{|c|c|c|c|c|}
\hline \multirow[b]{2}{*}{ Extent of influence } & \multicolumn{2}{|l|}{ Headteachers } & \multicolumn{2}{|l|}{ Teachers } \\
\hline & Frequency (f) & Percent (\%) & Frequency (f) & Percent (\%) \\
\hline To a large extent & 5 & 29.4 & 47 & 49.5 \\
\hline To a moderate extent & 9 & 52.9 & 7 & 7.4 \\
\hline To a little extent & 2 & 11.8 & 29 & 30.5 \\
\hline Not at all & 1 & 5.9 & 12 & 12.6 \\
\hline Total & 17 & 100.0 & 95 & 100.0 \\
\hline
\end{tabular}

The implication of this statistic in Table 4.is that the majority of the headteachers and teachers $(52.9 \%$ and $49.5 \%$ respectively) identified that the working conditions influenced their job commitment to a large extent. This shows that there was a significant influence of the working condition and the level of job commitment. This is in agreement with the study carried out by Masengo (2010) who established that the socio-psychological work environment of teachers in primary schools in Starehe district is very low. The results were also in line with Gupta (2009) on the argument that the work environment affects the socio-psychological wellbeing of workers. He further states that the mindset of workers at any place of work provides conducive social environment.

\subsection{Research Question 2 : To what extent does job security influences teachers' job commitment in public primary schools in Mwatate Sub County?}

Given that people tend to attach a lot of value to tangible things that meet their immediate every day expectations, job security is considered as an indirect factor that is much more effective as a job commitment motivating variable. The second objective of the study sought to determine whether job security influence teachers' job commitment in public primary schools in Mwatate Sub-County Kenya. In measuring the influence of job security on teachers' job commitment, the respondents were issued with statement to which they were expected to respond using the likert scale: Strongly Agree (SA), Agree (A), Not Sure (NS), Disagree (D), and Strongly Disagree (SD). Headteachers' responses are captured Table 5.

Table5. Influence job security on teachers' job commitment as perceived by headteachers

\begin{tabular}{|l|l|l|l|l|l|l|l|l|l|l|l|}
\hline \multicolumn{1}{|c|}{ Item } & \multicolumn{2}{c|}{ SA } & \multicolumn{3}{c|}{ A } & \multicolumn{2}{c|}{ NS } & \multicolumn{3}{c|}{ D } & \multicolumn{2}{c|}{ SD } \\
\cline { 2 - 12 } & $\mathbf{F}$ & $\mathbf{\%}$ & $\mathbf{F}$ & $\mathbf{\%}$ & $\mathbf{F}$ & $\mathbf{\%}$ & $\mathbf{F}$ & $\mathbf{\%}$ & $\mathbf{F}$ & \% \\
\hline $\begin{array}{l}\text { I feel teaching job is secure in terms of } \\
\text { future benefits. }\end{array}$ & 8 & 41.7 & 9 & 52.9 & 0 & 0.0 & 0 & 0.0 & 0 & 0.0 \\
\hline I stand to lose if I quit teaching job. & 4 & 23.5 & 8 & 47.1 & 0 & 0.0 & 0 & 0.0 & 5 & 29.4 \\
\hline $\begin{array}{l}\text { My current job is promising in terms } \\
\text { of allowances and fringe benefits. }\end{array}$ & 2 & 11.8 & 3 & 17.6 & 0 & 0.0 & 4 & 23.5 & 9 & 52.9 \\
\hline $\begin{array}{l}\text { My employer offers retirement gains, } \\
\text { medical insurance and leaves. }\end{array}$ & 15 & 88.2 & 2 & 11.8 & 0 & 0.0 & 0 & 0.0 & 0 & 0.0 \\
\hline $\begin{array}{l}\text { Teachers' needs and desires are met by } \\
\text { the employer. }\end{array}$ & 0 & 0.0 & 5 & 29.4 & 0 & 0.0 & 4 & 23.5 & 11 & 64.7 \\
\hline
\end{tabular}

According to results presented in Table 5 Majority of the headteachers were of the opinion that job security influences teachers' job commitment. This was shown by the high agreement of the head teachers on statements showing that job security influence teachers' job commitment. For instance, all $(100 \%)$ headteachers stated that they felt that the teaching job is secure in terms of future benefits. According to 47.1 percent of the headteachers they stand to lose if the quit the teaching job. This shows that teachers had a level of contentment with the job security offered by their employer. However, 11 (64.7\%) of the headteachers did not think that teachers' needs and desires are met by the employer. Prompting the researchers to try and establish teachers' views on their job security and work commitment. Table 6 presents the study findings. 
Table6. Influence job security on teachers' job commitment as perceived by teachers

\begin{tabular}{|l|c|c|c|c|c|c|c|c|c|c|}
\hline \multicolumn{1}{|c|}{ Item } & \multicolumn{2}{|c|}{ SA } & \multicolumn{2}{|c|}{ A } & \multicolumn{2}{|c|}{ NS } & \multicolumn{2}{c|}{ D } & \multicolumn{2}{c|}{ SD } \\
\cline { 2 - 11 } & $\mathbf{F}$ & $\mathbf{\%}$ & $\mathbf{F}$ & $\mathbf{\%}$ & $\mathbf{f}$ & $\mathbf{\%}$ & $\mathbf{F}$ & $\mathbf{\%}$ & $\mathbf{f}$ & $\mathbf{\%}$ \\
\hline $\begin{array}{l}\text { My current employer supports teachers' future } \\
\text { employment benefits like pension schemes. }\end{array}$ & 4 & 4.2 & 9 & 9.5 & 6 & 6.3 & 12 & 12.6 & 64 & 67.4 \\
\hline I stand to lose if I quit this current employer. & 12 & 12.6 & 7 & 7.4 & 0 & 0.0 & 23 & 24.2 & 53 & 55.8 \\
\hline $\begin{array}{l}\text { My job is promising in terms of allowances and } \\
\text { fringe benefits. }\end{array}$ & 49 & 51.6 & 22 & 23.2 & 2 & 2.1 & 9 & 9.5 & 13 & 13.7 \\
\hline $\begin{array}{l}\text { My current employer offers me leave, medical and } \\
\text { housing facilities. }\end{array}$ & 2 & 2.1 & 4 & 4.2 & 0 & 0.0 & 73 & 76.8 & 16 & 16.8 \\
\hline $\begin{array}{l}\text { My employer allows me membership to trade } \\
\text { unions, Sacco's and social welfare associations. }\end{array}$ & 64 & 67.4 & 9 & 9.5 & 2 & 2.1 & 9 & 9.5 & 11 & 11.5 \\
\hline
\end{tabular}

Implied by the statistics in Table 6 is that most public primary schools in Mwatate Sub-County were insensitive to the implementation of distinctive job security measures put up by their employer to enhance their job commitment as indicated by $(51.7 \%)$ of the respondents.

The process of motivation is meant to result in an enhanced teachers job commitment and to effectively motivate using job security, institutions should initiate diverse engagements which may lead to the satisfaction of the various needs of different teachers, It is common knowledge that people are likely to attach different values to different incentives. Table 6 . clearly shows that a majority $(61.7 \%)$ of teachers felt that they were less secure in their jobs and hence it was difficult to have them totally in their job According to Adegal (2011), rewards should be varied to satisfy both the immediate needs and long impression of the worker. In order to effectively motivate people to improve job commitment, rewards should be made frequently so that the vigurr to work hard is equally facilitated. In this context, Table 6 is actually a confirmation that most public primary schools (60.0\%) disregard teacher motivation through provision of rewards frequently as these were only done occasionally with learners. In this respect it was hardly easy to encounter many teachers commuting to their job assignment in Mwatate Sub-County. .

\section{CONCLUSIONS AND RECOMMENDATIONS}

\subsection{Conclusion}

The research has established that socio-psychological work environment was an issue in the area since teachers lacked proper socio-psychological work environment within the school compound which in turn affected their job commitments. Most of the teachers complained that lack of a supporting work environment has affected their commitment in their work. This has been a study in how a teacher's action to be dedicated and committed can be affected by the negative context of the school environment.

The research has also been able to confirm that most of the schools in the sub-county were insensitive to the implementation of job security strategies. This means that most of the public primary schools in the area had not put in place mechanism of motivating teachers so as to improve performance by offering long-term job security measures. Majority noted that if any, the job security measures were less diverse and were only available occasionally to the those teachers employed by the TSC rather than BOM teachers. Since there are a good number of BoM teachers in the sub-county, poor job commitment levels have become a negative factor affecting institutional management in the region. .

\subsection{Recommendations of the Study}

In order to be effective and efficient in the provision of basic education in the sub-county, the Ministry of Education should ensure that they improve socio-psychological work environment in public primary schools so that teachers willingly engage in extra time to assist pupils and thus, makes teachers to become committed in their jobs. They should also formulate strategies and measures that can improve commitment of teachers through teacher-pupils contact time.

\section{REFERENCES}

[1] Abdullah, A. \& Ramay. I.R. (2012). Antecedents of Organizational Commitment of Banking Sector Employees in Pakistan. Serbian Journal of Management. 
[2] Adegal, J. (2011). Influence of motivational Rewards on Workers Performance in Public Organizations in Vihiga District. MEd. Project, University of Nairobi.

[3] Ahmad, N; \& Oranye, N.O (2010) Empowerment, job satisfaction and organizational commitment: A comparative analysis of nurses working in Malasia and England" Journal of Nursing management.

[4] Armstrong, M. (2009). Human Resource Management Practice, Kagen page, Revised $11^{\text {th }}$ Edition, London, Uk.

[5] Best, J. W. \& Kahn, J. W. (2002). Research in Education ( $8^{\text {th }}$ Ed). New Delhi: Allyn and Bacon.

[6] Buchanan, I.,(1974). Building Organizational Commitment; the Socialization of managers in work Organization. Administrative Science Quarterly.

[7] Buitendach , J \& De Witte, H. (2005). Job insecurity, Extrinsic and Intrinsic job satisfaction and Effective Organizational Commitment of maintenance workers in Parasternal. South Africa Journal of Business Management. Vol 36.

[8] Coetsee, L. (1999). From Resistance to Commitment. Public Administration Quarterly.

[9] De Cuyper, N; et al (2009). Job insecurity and employability in fixed-term contractors, agency workers, and permanent workers; Associations with job satisfaction and affective organizational commitment. Journal of Occupational Health Psychology.

[10] Dirani, K. M:\& Kunchike, K. P. (2011). Job satisfaction and organizational commitment: Validating the Arabic correlations, and investigating the effects of demographic variables in the Lebanese banking sector. The international Journal of Human Resource Management.

[11] Diwani,R.K, (2007). Factors affecting performance in KCPE in Magarini Sub-county of Malindi District; Nairobi: University of Nairobi Press.

[12] Douglas, H. (2004). Influence of Motivation on Employee Performance in private Institutions: Focus on the Human Resource Management for Organizational productivity in Brazil.

[13] Farrell, J. P. (1993). Teaching the Developing Countries. The World Bank Washington DC.

[14] Folger, R. \& Crompanzano, R. (1998). Organizational Justice and Human Resource Management, Sage Publications, London.

[15] Gupta, C.B. (2009). Human Resource Management, Sultan Chand and Sons Educational Publishers revised $11^{\text {th }}$ edition, New Delhi.

[16] Holmgren, J. et al (1999). A Two dimensional approach to job insecurity, consequences for employee attitudes and wellbeing. European Journal of work and organizational psychology vol.8

[17] Herscovitch, L; Meyer, J.P (2002).Commitment to organizational change: Extension of a three-component model, the journal of applied psychology.

[18] Heyneman, P. (1976). Social Economic Status and Test Performance. Among Uganda Primary School children comparative Education. Review Vol.20.No.1.

[19] Kageha, Z. A. (2008). The effect of motivation on teachers' performance and its impact, on K.C.S.E results. A case of Titiki West Division, Vihiga district, Kenya. Unpublished MED project Kenyatta University.

[20] Kerlinger, F.N (1973). Foundation of Behavioural Science, New York, Holt, Renehard and Winston.

[21] Kirmizi, A. \& Deniz, O. (2009). The Organizational Commitment of IT, Mediterranean Conference on Information Systems, July 13 - 14, 2009.

[22] Kombo, D.K and Tromp, D.L A. (2006). Proposal and Thesis writing, Nairobi, Pauline Publication.

[23] Levine D.U \& Lezotte L.W. (1993) Unusually Effective Schools: A Review and Analysis of Research and Practice Madison: Wisconsin National Center for Effective Schools

[24] Malhotra et al, (2007). Linking rewards to commitment; an Empirical investigation, International Journal Resource Management, Vol 18, UK Call centres.

[25] Mamona, C.B \& Gankar S.V (2005) personnel management, text 7 cases, Himalaya Publish House Mumbai.

[26] Mark, W.L, et al, (2003) Evaluation; A systematic approach; $7^{\text {th }}$ Edition. Sage publications.

[27] Martin, A.O,(1967). Welfare at work, Batsford publishers, London.

[28] Masengo, J.W. (2010). Influence of school motivational practices on job performance by public primary school teachers in Starehe District, Nairobi: Kenya, Master Thesis, University of Nairobi.

[29] Mercurio, Z.A. (2015) Effective commitment as a core Essence of Organizational Commitment an integrative Literature Review.

[30] Meyer, J.P; Allen N. J (1991). A three-component conceptualization of organizational commitment. Human Resource Management Review. Vol 1.

[31] Meyer, P. J., \& Allen, J. N. (1997). Commitment in the workplace: Theory, research, and application. Thousand Oaks, CA: Sage. 
[32] Meyer, P. \& Allen J.N, (2002). Affective, continuance, and normative commitment to the organization: A meta-analysis of antecedents, correlates, and consequences. Journal of Vocational Behavior.

[33] Mowday, R.T et al, (1979). The management of organizational commitment, Journal of vocational behaviour, vol. 14.

[34] Mowday, R.T. et al, (1982). Employee-organization linkages: The psychology of commitment, absenteeism and turnover. New York. Academic Press.

[35] Mugikuu M.W. (2012). Influence of teachers' motivation on students' performance in KCSE in public secondary schools in Kwale County. Unpublished Masters thesis. University of Nairobi.

[36] Mutwiri, E.M, (2015). Institutional Factors Influencing Job satisfaction in mixed Day secondary schools in Imenti South District- Kenya. Unpublished MEd. Project, University of Nairobi.

[37] Mwamba, A.W (2014). Teacher factors influencing implementation of Inclusive education Public primary schools in Nyangala Sub-county Taita Taveta county, Kenya. University of Nairobi Press.

[38] NEPAD, (2009). Education and Training: Annual Report Programme of the African Union.

[39] Nthumo, T.M. (2015). Influence of Institutional Factors in pupils' performance in KCPE in public primary schools in Kangundo Sub-county, Machakos County, Kenya. Unpublished MEd. Project, University of Nairobi.

[40] Nzuve, S.N. (2010). Management of H. Resources of Kenya Perspective revised $4^{\text {th }}$ edition, Nairobi: Basic Modem Management Consultant.

[41] Ofogebe, W.N \& Ezugoh,T.C,(2010). Teachers' motivation and its influence on Quality Assurance in the Nigeria Education system. An international multi-disciplinary Journal, Ethiopia.

[42] Ogula, P. (1998). A handbook in Educational Research. Nairobi: New Kemit Publishers.

[43] Orodho, A.J., (2009). Elements of Education and Social Science Research Methods, Second Edition. Maseno: Kanezja.

[44] Ramachadran, V.; Jain S.; Shaker, J. S. \& Pal, S.M. (2005). Teachers Motivation in India. New Delhi.

[45] Republic of Kenya, (2007). Kenya Vision 2030: A Global Competitive and Prosperous Kenya, Government printers, Nairobi.

[46] Shore, L.M., \& Martin, H.J. (1989). Job satisfaction and organizational commitment in relation to work performance and turnover intentions. Human Relations, Vol 42.

[47] Siders, M.A., George, G. and Dharwadkar, R. (2001), The relationship of internal and external commitment foci to objective job performance measure, The Academy of Management Journal, Vol 44.

[48] Solinger, O. N: Van Olffen, W: Roe R. A (2008). Beyond the three-component model of organizational commitment. Journal of Applied Psychology.

[49] Steers, R. M. (1977). Antecedents and outcomes of Organizational commitment, Administrative Science Quarterly. Vol 22.

[50] Taita Taveta County Government, (2013). Causes and Remedies of declining Education in Primary schools in Taita Taveta County. Task Force Report, Wundanyi.

[51] Thomas, K.W \& Velthonce, B.A (1990). Cognitive Elements of Empowerment. An interpretive Model of Intrinsic Task Motivation, Academy of Management, Vol 15.

[52] Uygur, A. \& Kilic, G. (2009). A study into organizational commitment and job involvement. Ocean journal of applied sciences vol. 2

[53] VanVeldhoven, M. \& Meijman, T. F. (1994). The Measurement of Psychosocial Strain at Work: The questionnaire experience and evaluation of work. Amsterdam: NIA

[54] Warra, et al (1970). Evaluation of Management Training: Aldershot, Gower.

[55] Zakela, M. (2010). Influence of employee remuneration on organizational performance. A case study of public secondary schools in Roba location, Zambia.

Citation: Genevieve Wanjala, PhD, Mwashigadhi Lonex Joram, Med. "Impact of Socio-Psychological Work Environment on Teachers' Job Commitment in Public Primary Schools in Mwatate Sub-County, Kenya". International Journal of Humanities Social Sciences and Education (IJHSSE), vol 5, no. 5, 2018, pp. 19-28 doi: http://dx.doi.org/10.20431/2349-0381.0505003.

Copyright: (C) 2018 Authors. This is an open-access article distributed under the terms of the Creative Commons Attribution License, which permits unrestricted use, distribution, and reproduction in any medium, provided the original author and source are credited. 